\title{
15. Collectivism, consensus and concepts of shared leadership in movements for social change
}

\author{
Marian Sawer ${ }^{1}$ and Merrindahl Andrew ${ }^{2}$
}

In the 1970s, 'leadership' was a dirty word for many in the women's movement. Journalists trying to find a 'spokesman' complained of how upset women became if they were labelled as leaders. Leadership was associated with hierarchy and hierarchy was seen as inextricably linked with the patriarchal domination of women. To liberate themselves from patriarchy, women were trying to organise without hierarchy, through collectives and networks. Instead of there being leaders and followers, women would empower themselves through taking responsibility for decisions, which would be reached by consensus.

At first there were attempts not only to resist the idea of leaders but also to do without structure at all. It was soon realised, however, that this could lead to unacknowledged and unaccountable leadership as informal power relations emerged. In an influential essay, American feminist Jo Freeman called this the 'tyranny of structurelessness'. Freeman's essay was roneoed and distributed widely within the women's movement, both in the United States and in Australia. It proved an important influence in the development of feminist organisational philosophy: it was better to have democratic structures than none at all. Freeman's democratic principles included delegating authority for specific tasks, requiring accountability to the group, distributing authority as widely as possible, rotating tasks and ensuring access by all members to information and other resources. ${ }^{3}$

The new feminist experiments with organisational structures were seen as a model by those like Bruce Kokopeli and George Lakey who were seeking alternative structures to fulfil the functions of leadership in movements for social change. They described the feminist approach as one of 'shared leadership' and as demonstrating that while leadership was needed, leaders were not. ${ }^{4}$ Leadership was seen not as an attribute of individuals but rather as a number of functions that could be shared flexibly among members. Functions could be

\footnotetext{
1 The Australian National University.

2 The Australian National University.

3 Joreen Freeman, 'The Tyranny of Structurelessness', Reprinted from The Second Wave 2(1) (Sydney: Words for Women, 1972).

4 Bruce Kokopeli and George Lakey, Leadership for Change: Towards a Feminist Model (Philadephia: New Society Publishers, 1978), 7.
} 
divided between the task functions of goal-setting and goal accomplishment and the morale functions of nurturing the group through attention to process and emotional climate. A valuable aspect of the feminist model was to make morale functions a central part of leadership. Too often this function had been invisible in the older models of leadership, leaving it to women to do the emotion work without any corresponding leadership status. ${ }^{5}$

In this chapter we explore the initial rejection by second-wave feminists of the concept of leadership, the development of the concept of shared leadership, and later compromises that built on both feminist organisational philosophy and the expectation that women would do leadership differently because of their socialisation and family roles. We look at how these philosophies and expectations were also carried into other movements for social change and to what extent more collaborative ideas of leadership with emphasis on empowering others are being carried forward in these movements.

\section{Rejecting masculine models of leadership}

Because of the extent of the discursive shift that has taken place in Western democracies and the current pre-eminence of individualistic norms, it can be a shock to rediscover the collectivist frames that were so common in the 1970s. A good example can be found in a Penguin book published in Melbourne in 1975, a collection called The Other Half: Women in Australian Society, edited by Jan Mercer. The contributors included a number of future university professors and one future vice-chancellor. But far from presenting themselves as academic leaders, these outstandingly talented women did not even attach their names to their contributions. The book explained:

The names of contributors are not listed on the contents page or linked with the contributions in the body of the book, as it is the ideas themselves rather than who presented them that is crucial. Nor is it relevant to indicate the academic status of individual writers because these have been allocated in terms of a male dominated and defined system of rewards. ${ }^{6}$

The second wave of the women's movement was in part reacting to the way in which gender hierarchy had reasserted itself in the radical movements of the 1960s. Men had taken the microphone and expected women to type the minutes. In the new women's services that were springing up from 1974, women sought to replace individual leaders by democratically sharing the functions of

5 Ibid., 16-20.

6 Jan Mercer, ed., The Other Half: Women in Australian Society (Melbourne: Penguin, 1975), 5. 
leadership within the group. Functions included not only setting and achieving goals but also maintaining group morale and nurturing members. The concept of shared leadership was embodied in the flatter structures adopted by women's movement organisations (matrices rather than hierarchies) and the emphasis on democratic process and consensus decision-making. This philosophy was seen as reflecting preferred female ways of organising and as supporting the empowerment of women. Even when the consensus model was modified, it was through the horizontal delegation of routine decision-making, with major decisions continuing to be decided by consensus - the preferred route to empowerment through everybody 'winning'.

The emphasis on consensus was part of what the late activist and academic Wendy Weeks describes as a distinctive form of organising, characterised by the 'pursuit of collectivity'. ${ }^{8}$ This pursuit, Weeks argues, is rooted in the long histories of women's involvement in family, neighbourhood and community, but became politicised in the 1970s in Western countries including Australia. Feminists developed a form of organising that emphasised leadership acts, which could be shared by a number of people, rather than viewing leadership as synonymous with charismatic individuals. ${ }^{9}$ Accordingly, 'negotiations of the social order' needed to be ongoing and invite questioning, rather than closing off debate in order to achieve a goal.

The refusal to separate means and ends and an ethic of continual feminist analysis involve 'locating theory and practice within the tension between the diverse individual women's experiences ... and an analysis of the economic, political and social arrangements, processes and related ideas and beliefs' ${ }^{\prime}{ }^{10}$ As Brown observes in relation to the UK Women's Centres, '[o]rganising activity ... makes reference to the values of the autonomous women's movement, but ... the relationship between values and action is one which is continually negotiated by participants'. ${ }^{11}$ This means that no one leader can be taken to embody the values of the movement, and attempts at such representation have often been vigorously contested.

Such demanding principles certainly make it difficult for women's movements to operate in a broader social order that values individual success and goal attainment over all. Yet this very difficulty has been part of the reasoning behind feminist organising: the challenges faced by women in creating alternative models

\footnotetext{
7 Kathleen P. Iannello, Decisions without Hierarchy: Feminist Interventions in Organization Theory and Practice (New York: Routledge, 1992), 120-1.

8 Wendy Weeks, 'Democratic Leadership Practices in Australian Feminist Women's Services: The Pursuit of Collectivity and Social Citizenship?', International Review of Women and Leadership 2 (1996): 19-33.

9 Helen Brown, Women Organising (London: Taylor \& Francis, 2002 [first published 1992]).

10 Wendy Weeks, 'Feminist Principles for Community Work', Women in Welfare Education, 7 (October 2004): 1-16 [reprinted from Women in Welfare Education 1 (1994)].

11 Brown, Women Organising, 53.
} 
of collective action are seen to prefigure the struggle to bring about broader changes in society as a whole. This conflict is acute in relation to principles of leadership. The conventional vision of leadership maintains that, as well as embodying the vision and goals of the movement, leaders provide 'someone who can speak with authority on behalf of the movement' to governments and the public. ${ }^{12}$ This expectation has been a challenge for women's movements, emerging as conflict over 'media stars' and questions of who can legitimately speak for whom.

\section{Operationalising ideas of shared leadership}

Ideas of shared leadership had a very broad influence in the women's movement in the 1970s as activists called on women to 'stop mirroring men's institutions and behaviours'. ${ }^{13}$ The determination to avoid hierarchy was true even of the second-wave organisations most dedicated to 'reformist' goals of influencing government. This was in contradiction to received wisdom on effective lobbying, which suggested that organisations should mirror the agencies of government they were trying to influence. For example, when the Women's Electoral Lobby (WEL) held its first national conference immediately after the 1972 federal election, the NSW paper on how WEL should be organised reported: 'We are determined to avoid having leaders - either convenors or permanent spokeswomen or any form of power hierarchy.' ${ }^{14}$

These ideas were not only being put into practice in advocacy organisations and women's services; there were also attempts to carry them into government. Sara Dowse, the first head of the Women's Affairs Branch in the Australian Department of Prime Minister and Cabinet, told of the discomfort of the new feminist bureaucrats (femocrats) with the hierarchical ladder they were given. In protest, when the next woman on the ladder was promoted she said she would not accept the promotion unless the woman below her was promoted as well, which also led to promotions for others. ${ }^{15}$ Another early femocrat spoke of the unresolved issue of how to 'get from the values we hold dear - of collective,

\footnotetext{
12 Karen O'Connor and Alixandra B. Yanus, 'Overview: History of Women Leaders in Social Movements', in Gender and Women's Leadership: A Reference Handbook. Volume 1, ed. Karen O'Connor (New York: Sage, 2010), 182.

13 Weeks, 'Feminist Principles for Community Work', 10; Marian Sawer and Abigail Groves, “"The Women's Lobby": Networks, Coalition Building and the Women of Middle Australia', Australian Journal of Political Science 29 (1994): 441.

14 Marian Sawer, Making Women Count. A History of the Women's Electoral Lobby in Australia (Sydney: UNSW Press, 2008), 94.

15 Sara Dowse, 'Address to WEL-ACT Dinner', Canberra, 5 June 1989.
} 
non-hierarchical democratic behaviour - to the outcome we seek, of a peaceful world safe for women ... without sacrificing these values in the rush to seize and use power on behalf of feminist ends ${ }^{\prime}{ }^{16}$

In New Zealand the first head of the Ministry of Women's Affairs tried to minimise hierarchy. She practised collectivism and decisions were talked through until consensus was reached. At the weekly staff meeting time was allocated for staff to mention issues that were impinging on their public role, such as children who were teething. ${ }^{17}$ As we have seen, the emphasis on emotion work as part of leadership was intrinsic to feminist organisational philosophy; this meant relating to the whole person and particularly to the roles fulfilled by women outside the organisation. Setting aside time to ensure that personal concerns could be shared was one aspect of this.

Attempts to import feminist values into a somewhat unreceptive bureaucracy led to numerous cultural clashes. For example, a WA premier tried to find who was 'in charge' of his Women's Information and Referral Exchange (WIRE) and hence who could be held responsible for sending out letters about a women's peace camp through the premier's department. Being frustrated by WIRE's flat structure and not being able to find anyone in charge, he shouted 'you're all fired'. ${ }^{18}$

In Victoria as well, the Women's Information and Referral Exchange was established under the premier's department in 1983-84. The original proposal was put forward by WEL and the Young Women's Christian Association (YWCA). After the Office of Women's Affairs in the premier's department conducted consultations with some 200 women's organisations, a constitution was adopted that included the purposes of upholding the principles of feminism and functioning 'within a democratic non-hierarchical organisational structure which includes flexibility and collective decision-making'. It did not have a coordinator, instead having a series of collectives to perform coordination and other functions. Tasks involved in collective meetings were all rotated and until 1988 WIRE annual reports did not reveal who belonged to any of the collectives, in accordance with a policy of attributing all work to the collective rather than naming individual members. ${ }^{19}$ No wonder it was described as 'a libertarian classroom in an authoritarian school', given the very different organisational values of the government departments which funded it. ${ }^{20}$

16 Hester Eisenstein, Gender Shock (Boston: Beacon, 1992), 3.

17 Marian Sawer, 'Femocrats and Ecorats: Women's Policy Machinery in Australia, Canada and New Zealand', in Missionaries and Mandarins: Feminist Engagement with Development Institutions, eds Carol Miller and Shahra Razavi (London: Intermediate Technology Publications, 1998), 130.

18 Marian Sawer, Sisters in Suits: Women and Public Policy in Australia (Sydney: Allen \& Unwin, 1990), 203.

19 Ibid., 197.

20 Sara Dowse, 'The Bureaucrat as Usurer', in Unfinished Business: Social Justice for Women in Australia, ed. Dorothy Broom (Sydney: Allen \& Unwin, 1984), 154. 
As noted, at the height of women's movement mobilisation there were attempts to import the anti-hierarchical spirit of the women's movement even into the heart of government. Sara Dowse claimed at an International Women's Year conference in 1975 that the wheel model of women's affairs, with its hub in a central coordinating department and spokes in functional departments, was in harmony with feminist organisational philosophy. ${ }^{21}$ She thought that in society at large one could generalise that there was a central autonomous women's movement and then feminist caucuses in places such as the media, the public service and the unions, which related back to the central autonomous movement. The same model could apply within the public service, with a central core linked to caucuses in every other area of the public service. This wheel of women's affairs, which was about to come into existence at the federal level, became the Australian model for women's policy machinery: it was a centre-periphery model, rather than one characterised by vertical integration. Of course the term 'feminist caucuses' would not be used in organisational charts, but rather 'women's desks', 'women's units' or, later, 'gender focal points'. Nonetheless, in the late 1980s senior federal bureaucrats were still referring to the oldest of the women's units, the Women's Bureau, as 'the feminist collective'.

\section{Women in management: Making a difference?}

Meanwhile, during the 1980s a literature emerged on women in management, much of it inspired by Rosabeth Moss Kanter's Men and Women of the Corporation. ${ }^{22}$ Kanter made the case for the importance of relative proportions. While there were still only token numbers of women in an organisation they experienced dynamics such as boundary heightening, reminders of difference and loyalty tests, and there were enormous pressures to conform to the culture of the dominant group. Kanter argued that a shift in relative proportions and the achievement of 'critical mass' could mean that minorities were able to initiate serious change in the culture of the organisation. Kanter's work inspired Danish political scientist Drude Dahlerup to investigate whether the concept of critical mass could be useful in analysing under what circumstances women politicians were able to make a difference. She found that the concept was not really transferable to parliament, where critical actors were more important in achieving change than numbers alone. ${ }^{23}$

\footnotetext{
21 Sara Dowse, 'Power in Institutions - The Public Service', Transcript of discussion at the Women and Politics Conference 1975, National Library of Australia, Canberra, 1975, 12.

22 Rosabeth Moss Kanter, Men and Women of the Corporation (New York: Basic Books, 1977).

23 Drude Dahlerup, 'From a Small to a Large Minority: Women in Scandinavian Politics', Scandinavian Politics Studies 11 (1988): 275-97.
} 
Nonetheless the concept of critical mass lived on to inspire a worldwide movement for electoral quotas to ensure there were enough women elected to parliaments to bring about change. It was widely believed that because of the roles women played in the family they would bring a more consensus-seeking approach to politics and that, once there were enough of them, political culture would shift away from more confrontational styles. This gendered expectation of what might be possible when women became 'a large minority' in organisations was also reflected in the new literature on women in management.

For example, in 1990 Judy Rosener published a famous article in the Harvard Business Review arguing that women managers were now feeling freer to depart from the masculine styles that had been the norm of successful management and which the first women executives had felt obliged to follow. The masculine leadership style had been one of command and control, using organisational status and manipulation of rewards (something labelled in the 1970s as a 'transactional' form of leadership). ${ }^{24}$

Rosener found that women were now relying more on their interpersonal skills and using them to motivate others through sharing power and information, encouraging participation and affirming others' contributions. Her interviewees made constant reference to creating mechanisms to make people feel part of the organisation - something Rosener described as an interactive and inclusive style of leadership. She argued that women were succeeding, particularly in fast-changing and growing organisations, because of, rather than despite, characteristics generally regarded as 'feminine' and hitherto as inappropriate in a leader. ${ }^{25}$

Rosener's article stimulated a range of reactions. Cynthia Fuchs Epstein suggested it reflected bias in the self-reporting of management styles: both male and female managers were reporting what they saw to be a gender-appropriate management style. ${ }^{26}$ The confirmation that shared leadership was seen as a 'feminine' management style and transactional leadership as a 'masculine' style was itself interesting, highlighting the pressures on women and men to define themselves in relation to these stereotypes. ${ }^{27}$ Rosener's article had many resonances for those who wished to demonstrate that there was a feminist way of doing leadership, that women should not shrink from exercising power and

\footnotetext{
24 James McGregor Burns, Leadership (New York: Free Press, 1978).

25 Judy Rosener, 'Ways Women Lead', Harvard Business Review (November-December 1990): 120.

26 Cythia Fuchs Epstein, 'Ways Men and Women Lead: Debate', Harvard Business Review (JanuaryFebruary 1991): 150-1.

27 Joyce K. Fletcher, 'The Paradox of Postheroic Leadership: An Essay on Gender, Power, and Transformational Change', Leadership Quarterly 15(5) (2004): 650.
} 
that women could make a difference. Naomi Wolf later wrote a bestseller setting out a case for 'power feminism' called Fire with Fire: The New Female Power and How to Use It. ${ }^{28}$

In Australia, Amanda Sinclair, soon to become foundation professor of management (diversity and change) at the University of Melbourne, was arguing that organisations needed to build in more diversity in order to facilitate flexibility and adaptability. As women moved up the organisational hierarchy, they tended to reject their own distinctive managerial traits in order to better fit into male models of leadership and managerial success. This discouragement of diversity meant a loss of organisational effectiveness, particularly in terms of capacity to respond and adapt to rapidly changing circumstances. ${ }^{29}$ Another sign of the times was the establishment in 1995 of the journal International Review of Women and Leadership by feminist management expert Leonie Still.

WEL advocate and public intellectual Eva Cox joined in with the book Leading Women: Tactics for Making a Difference. She began by discussing the discomfort many women felt with the concepts of power and leadership, even women being groomed for senior levels in the public service. She found that for many women the concepts of power and leadership were 'so identified with certain masculine values that they found it difficult even to discuss them' ${ }^{30}$ She went on to urge feminists to become more comfortable with power. As part of her argument, she referred to how the models of shared leadership associated with the women's movement were now being taken up by management manuals that advocated flatter structures and having time for family and community. ${ }^{31}$

Judy Wajcman presented a less sanguine view in the same year (1996). Reporting on a survey she had conducted of male and female managers in five multinational companies, she found that in an economic climate of downsizing and a context of strong organisational imperatives, women were conforming to older male norms of management. While both male and female managers used the rhetoric of consultative and people-oriented management, in fact there had been a return to macho management styles. ${ }^{32}$

But feminists continued to hope that an alternative form of leadership was possible. Joan Kirner, the first woman Premier of Victoria, published a book together with human rights advocate Moira Rayner that drew on many of her experiences in government. It was called The Women's Power Handbook and

28 Naomi Wolf, Fire with Fire: The New Female Power and How to Use It (London: Chatto \& Windus, 1993).

29 Amanda Sinclair and Fern Marriott, 'Women in Management-Advantage through Adversity', Asia Pacific Human Resource Management 28 (1990): 14-25.

30 Eva Cox, Leading Women: Tactics for Making the Difference (Sydney: Random House, 1996), 24.

31 Ibid., 256.

32 Judy Wajcman, 'Desperately Seeking Differences. Is Management Style Gendered?', British Journal of Industrial Relations 34 (1996): 333-49. 
sought to establish that women were more likely to use power in a democratic way, to empower others. The authors suggested women were most likely to be seen exercising power 'through networking: acting collectively, persuading, consulting and influencing' ${ }^{33}$ Kirner drew on EMILY's List research to argue that it was not just a matter of different leadership preferences but also of voter expectations: women voters expected that women in parliament would ensure decision-making processes were more democratic and inclusive of women. ${ }^{34}$

\section{Hybrid organisations}

In women's services, the pressures of neoliberal reform and generational change led to the development of an innovative 'hybrid' form of organisation. This can be seen through the case of WIRE in Victoria, discussed earlier as an example of feminist organisational philosophy and collectivist practice. Like other women's services, WIRE eventually moved to a more traditional governance structure, with a chief executive officer from 2002, but retained strong elements of feminist organisational philosophy. There was a 'conscious effort to maintain the collaborative and participatory elements that were an integral part of the WIRE culture'.$^{35}$ These included the time set aside at the beginning of board meetings for the discussion of personal issues, reflecting the feminist emphasis on holistic rather than purely role-based relationships within organisations.

Like WIRE, the Canberra Rape Crisis Centre (CRCC) has gone through extensive changes since its establishment as a collective in 1976. Having debated the risks of government funding, in the early 1980s CRCC eventually accepted funds sufficient for one and a half workers - but then decided to share the funds equally between several workers, giving them an exceptionally low wage for full-day shifts that often extended to $8 \mathrm{pm} .{ }^{36}$ More insidious from a feminist point of view was the way that State agencies promoted individualised responses to rape (the 'treatment model') at the expense of the 'political analysis, activism and work to change social relations' for which rape crisis centres were founded. ${ }^{37}$ Despite this change, however, and the shift from a collective to a governance model in 2005, CRCC, like rape crisis centres generally, has maintained aspects of participatory decision-making and has continued to pursue a social change agenda.

33 Joan Kirner and Moira Rayner, The Women's Power Handbook (Melbourne: Penguin, 1999), 4.

34 Ibid., 236.

35 Kerry Jeanne Tanner, 'Emotion, Gender and the Sustainability of Communities', Community Informatics:

A Global E-Journal 1 (2005), http://ci-journal.net/index.php/ciej/article/view/208/165.

36 Veronica Wensing, 'What's Behind a Name? The Organisational Identity of Rape Crisis Centres: Positioning the Canberra Rape Crisis Centre as a Feminist Organisation in the 21st Century', Unpublished paper, 2009, 8.

37 Ibid., 12. 
The development of a 'hybrid' form of management is part of a broader pattern among women's services facing pressures from outside and within to adopt more formal structures of governance. Organisational scholar Karen Lee Ashcraft argues that feminist organisations have had to forge a compromise between a feminist commitment to collectivism and the need to keep organisations viable and effective over the long term, leading to 'organized dissonance', blending 'hierarchical and egalitarian models of power'.$^{38}$ In this form of organisation, the need to respond to conflicting imperatives creates a series of 'strategic tensions - pushes and pulls that become a check-and-balance system' ${ }^{39}$ In some ways, this embracing of tension carries forward the early women's liberation philosophy of continual questioning and ongoing feminist analysis (described above); however, this attempt to merge bureaucratic form and egalitarian practice faces some deep problems, including the tendency for bureaucracy to take over when 'relations of dominance/submission carry more cultural weight' in the broader society 'than those of equality'. ${ }^{40}$

Feminist organisations also highlight the importance of emotion in feminist concepts of leadership, in contrast with the rationality-centric approaches to management that have dominated Western countries in the twentieth century. While organisational theorists and sociologists have long challenged the overemphasis on rational decision-making, ${ }^{41}$ feminist services exemplify a fully developed practice of embracing emotion. These services confront the potential conflict between organisational imperatives and personal experience. One case study of WIRE, for example, contrasted the barren emotional landscape of many organisations with the vibrancy and warmth of a feminist community organisation [WIRE]', which 'manifests a skilful blending of rational and emotional elements'. ${ }^{42}$

In the new discursive environment of neoliberalism, where collectivist ideas were rarely heard anymore, leadership emerged as something the women's movement could embrace, even while promoting ideas that women's leadership could be different from the old masculine models. In 2010 the Australian Sex Discrimination Commissioner identified women and leadership as one of the five priority areas for achieving gender equality. There was also a proliferation of initiatives with titles such as Women and Leadership Australia, Centre for

38 Karen Lee Ashcraft, 'Organized Dissonance: Feminist Bureaucracy as Hybrid Form', Academy of Management Journal 44 (2001): 1301.

39 Ibid., 1304.

40 Ibid., 1304.

41 See, for example, Herbert Simon's concept of 'bounded rationality'. Herbert A. Simon, 'A Behavioral Model of Rational Choice', Quarterly Journal of Economics 69 (1955): 99-118. On rationality and emotion in social movement organisations, see also Merrindahl Andrew, 'Social Movements and the Limits of Strategy: How Australian Feminists Formed Positions on Work and Care' (PhD dissertation, The Australian National University, Canberra, 2008), https://digitalcollections.anu.edu.au/handle/1885/49281, 189-207.

42 Tanner, 'Emotion, Gender and the Sustainability of Communities'. 
15. Collectivism, consensus and concepts of shared leadership in movements for social change

Leadership for Women and the Women's Leadership Institute Australia. It was not just a matter of having women at the top; it was also thought that women's leadership could be more democratic and information-sharing or transformational rather than transactional.

\section{Movements for social change}

Compared with research on women's leadership in corporate and political life, there has until now been only limited analysis of women's leadership in social movements. Internationally, research in this area has explored four main themes. First, there have been studies of the leadership roles played by individual women. Second, research has documented the way gendered expectations continue to constrain women's leadership, even in supposedly 'progressive' movements for social change. Third, scholars have considered the often invisible emotional and relational work of women in social movements, thereby expanding our understandings of what leadership is. Finally, some researchers have considered how feminist organisational philosophy may have affected leadership practices in social movements.

The leadership roles played by individual women in social movements have attracted some attention and this is perhaps the most thoroughly researched aspect of the field. In Australia, for example, Local Heroes tells the stories of various people, most of them women, who have led local environmental campaigns such as those against pollution and industrial contamination. ${ }^{43}$ Editor Kathleen McPhillips notes that gender may be a significant factor, because of women's fears for their children's health. ${ }^{44}$ Jane Elix and Judy Lambert (this volume) confirm the significant role of maternal identity in motivating Australian women's environmental activism, while international evidence also suggests that collective identity as mothers can easily be mobilised in support of activism around issues such as industrial or nuclear contamination. ${ }^{45}$

The second theme explored by the literature is that of the constraints imposed on women's leadership roles by gendered expectations, even in movements for social change. Social movement scholars Aldon D. Morris and Suzanne Staggenborg argue that focusing too much on individual leaders risks overlooking the structural opportunities and obstacles to collective action'. The focus on leaders not only distracts attention from what enables collective action but also unfairly

\footnotetext{
43 Kathleen McPhillips, ed., Local Heroes: Australian Crusades from the Environmental Frontline (Sydney: Pluto Press, 2002).

44 Kathleen McPhillips, 'Introduction', in ibid., xi-xxiv, xix-xxii.

45 Alison E. Adams and Thomas E. Shriver, 'Collective Identity and Gendered Activism in the Czech Environmental Movement: The South Bohemian Mothers' Struggle against Nuclear Power', Research in Social Movements, Conflicts and Change 32 (2011): 163-89.
} 
relegates the actual membership of movements to the category of 'followers' ${ }^{46}$ Accordingly, they argue that we should look at social movement leadership within its structural contexts and acknowledge the different levels of leadership and roles of participants.

Gender is central to this critique. The North American authors observe that the 'degree of gender inequality in the community of a challenging group is one of the main determinants of gender inequality in top levels of leadership in social movements' ${ }^{47}$ They observe that women's lower status has typically been reproduced in movements' leadership profiles, with men taking on roles as public spokespeople (viewed as a leadership equivalent in social movements, where decentralisation may make it less clear who is actually 'in charge'). As prominent women's movement scholar Verta Taylor argues, '[e]mpirical research by feminist social scientists suggests that gender hierarchy is so persistent that, even in movements that purport to be gender-inclusive, the mobilisation, leadership patterns, strategies, ideologies and even the outcomes of social movements are gendered'. ${ }^{48}$

In line with leadership research generally, discussions about women leading movements for social change have often focused on the question of whether women have a distinctively feminine 'leadership style'. As Amanda Sinclair has argued, however, to focus on this question has inherent limits and can perpetuate oppressive gendered stereotypes, especially concerning caring and family responsibilities. ${ }^{49}$ Instead, we might ask what social pressure (for example, family responsibilities) and resources (such as friendships and networks) must be considered when analysing the role of women in movements. How have women leaders themselves conceptualised their roles, particularly in those cases where they have been engaged in the double struggle of trying to make their movements more gender-sensitive and women-friendly, while working towards the other goals of the movement?

The third type of literature on women leading social movements focuses on the relatively invisible emotional and relational work performed by women in these movements, which has not been part of more traditional concepts of leadership. In many cases the different roles taken in social movement activities are what mark out the different status of participants. In her study of African-American

\footnotetext{
46 Aldon D. Morris and Suzanne Staggenborg, 'Leadership in Social Movements', in The Blackwell Companion to Social Movements, eds David A. Snow, Sarah A. Soule and Hanspeter Kriesi (Malden, Mass.: Blackwell, 2004), 171.

47 Ibid., 176.

48 Verta Taylor, 'Gender and Social Movements: Gender Processes in Women's Self-Help Movements', Gender and Society 13 (1999): 8-9.

49 Amanda Sinclair, 'Not Just "Adding Women In": Women Re-Making Leadership', Paper delivered at Women, Leadership and Democracy in Australia Conference, Museum of Australian Democracy, Canberra, 1-2 December 2011.
} 
women in the civil rights movement, Belinda Robnett notes that while men tended to occupy formal roles as spokespeople/leaders, women often acted as 'bridge leaders', forming an 'intermediate layer of leadership, whose task includes bridging potential constituents and adherents, as well as potential formal leaders to the movement'.$^{50}$ She also argues that, in this bridging role, women have done much of the 'emotion work' of movements. As we noted earlier, part of the feminist critique of traditional concepts of leadership was the way in which such emotion work, essential to nurturing any organisation, was rendered invisible.

The way in which 'emotional gender rules' affect the distribution of leadership roles may be made explicit within social movements rather than simply remaining at the unconscious level. For example, the animal rights movement deliberately chose men to make its arguments in public, believing the movement's credibility would be undermined by women's 'emotional' claims. ${ }^{51}$ But it is not only the distribution of leadership roles but also the repertoires of social movements that are affected by emotional gender rules. This effect is illustrated by women's selfhelp practices in women's health movements as contrasted with the use of violent tactics in male-dominated nationalist, left-wing and right-wing movements. ${ }^{52}$

Finally, research has begun to analyse the influence of feminist organisational philosophy on the way leadership is practised in social movements. In doing so, such research steps back from the focus on individual leaders to consider the models of collective action in social movements. It looks not only at the organisational practices of the women's movement but also at the extent to which such practices have been carried into other movements for social change. For example, Suzanne Staggenborg argues that 'feminist organizations have been the main carriers of the "participatory democratic" mode of social movement organization since the 1960s and feminists have been influential in spreading this form of organization to other movements with similar concerns such as the antinuclear power movement'. ${ }^{53}$

\footnotetext{
50 Belinda Robnett, How Long? How Long? African American Women in the Struggle for Civil Rights (New York: Oxford University Press, 1997), 191.

51 Jeff Goodwin, James M. Jasper and Francesca Polletta, 'Emotional Dimensions of Social Movements', in The Blackwell Companion to Social Movements, eds David A. Snow, Sarah A. Soule and Hanspeter Kriesi (Malden, Mass.: Blackwell, 2004), 424.

52 Verta Taylor and Nella van Dyke, “"Get Up, Stand Up": Tactical Repertoires of Social Movements', in The Blackwell Companion to Social Movements, eds David A. Snow, Sarah A. Soule and Hanspeter Kriesi (Malden, Mass.: Blackwell, 2004), 276.

53 Suzanne Staggenborg, 'Can Feminist Organizations be Effective?', in Feminist Organizations: Harvest of the New Women's Movement, eds Myra Marx Ferree and Patricia Yancey Martin (Philadelphia: Temple University Press, 1995), 339.
} 
A study of the 1980s peace movement, for example, found that the ways in which the women's movement had influenced the peace movement included the adoption of organisational structures designed to avoid hierarchy. ${ }^{54}$

To what extent has the entry of feminists resulted in similar influences in other social movements? As the late Jane Elix points out, feminist organisational philosophy may make leadership a very complex issue. In the environment movement, as in other movements with limited material resources, charismatic leadership is highly valued but at the same time leaders are often expected to 'recognise and work within low hierarchy structures, favouring extensive internal consultation and inclusive decision-making'. ${ }^{55}$ To the extent that distinctively feminist models of organising have influenced these movements, can such influences be sustained as social movement organisations become professionalised? These questions remain largely un-researched in the area of Australian social movements but certainly in the environment movement there is a perceived departure by peak bodies from the collaborative organisational models found in grassroots campaigns.

Finally, we should consider how feminist organisational philosophies interact with the mainstream shift to 'post-heroic' ideas about leadership in corporate life. On the face of it, post-heroic leadership has much in common with feminist practices of organisation, envisioning as it does a shift 'from individual to collective, from control to learning, from "self" to "self-in-relation", and from power over to power with' ${ }^{56}$ In practice, however, heroic models of leadership are proving to be very resilient in corporate and political life, with rewards and promotions continuing to flow to those demonstrating traditionally 'masculine' leadership traits.

For decades now, non-profit and social movement organisations have been urged to adopt best practice from the corporate world, while government and corporate bodies have to some extent moved towards the more decentralised networks characteristic of social movements. Given that at least some social movement organisations have been influenced by feminist critiques of hierarchy and domination, have these organisations been able to transform leadership beyond the impasse of continued masculine privilege, and what factors have enabled or impeded this process? The inherently critical and questioning nature of social movements might predict a capacity to identify and change the gendered dynamics of leadership, but as we have seen, there are crosscutting

54 David S. Meyer and Nancy Whittier, 'Social Movement Spillover', Social Problems 41 (1994): 277-98.

55 Jane Elix, 'Leadership by Another Name: Women Coordinating, Influencing and Enabling within the Australian Environment Movement', Paper presented to the Women, Leadership and Democracy in Australia Conference, Museum of Australian Democracy, Canberra, 1-2 December 2011.

56 Fletcher, 'The Paradox of Postheroic Leadership', 650. 
pressures from professionalisation. Forty years on from the arrival of secondwave feminism's ideas of shared leadership, it is still too early to tell whether these can be sustained within and beyond the women's movement.

\section{References}

Adams, Alison E. and Thomas E. Shriver. 'Collective Identity and Gendered Activism in the Czech Environmental Movement: The South Bohemian Mothers' Struggle against Nuclear Power.' Research in Social Movements, Conflicts and Change 32 (2011): 163-89.

Andrew, Merrindahl. 'Social Movements and the Limits of Strategy: How Australian Feminists Formed Positions on Work and Care.' PhD dissertation, The Australian National University, Canberra, 2008. https://digitalcollections. anu.edu.au/handle/1885/49281.

Ashcraft, Karen Lee. 'Organized Dissonance: Feminist Bureaucracy as Hybrid Form.' Academy of Management Journal 44 (2001): 1301-22.

Brown, Helen. Women Organising. London: Taylor \& Francis, 2002 [first published 1992].

Cox, Eva. Leading Women: Tactics for Making the Difference. Sydney: Random House, 1996.

Dahlerup, Drude. 'From a Small to a Large Minority: Women in Scandinavian Politics.' Scandinavian Politics Studies 11 (1988): 275-97.

Dowse, Sara. 'Power in Institutions - The Public Service.' Transcript of discussion at the Women and Politics Conference 1975, National Library of Australia, Canberra, 1975.

Dowse, Sara. 'The Bureaucrat as Usurer.' In Unfinished Business: Social Justice for Women in Australia, edited by Dorothy Broom, 139-160. Sydney: Allen \& Unwin, 1984.

Dowse, Sara. 'Address to WEL-ACT Dinner.' Canberra, 5 June 1989.

Eisenstein, Hester. Gender Shock. Boston, Mass.: Beacon, 1992.

Elix, Jane. 'Leadership by Another Name: Women Coordinating, Influencing and Enabling within the Australian Environment Movement.' Paper presented at the Women, Leadership and Democracy in Australia Conference, Museum of Australian Democracy, Canberra, 1-2 December 2011. 
Diversity in Leadership: Australian women, past and present

Fletcher, Joyce K. 'The Paradox of Postheroic Leadership: An Essay on Gender, Power, and Transformational Change.' Leadership Quarterly 15(5) (2004): 647-61.

Freeman, Joreen. 'The Tyranny of Structurelessness.' Reprinted from The Second Wave 2(1), Sydney: Words for Women, 1972.

Fuchs Epstein, Cynthia. 'Ways Men and Women Lead: Debate.' Harvard Business Review (January-February 1991): 150-1.

Goodwin, Jeff, James M. Jasper and Francesca Polletta. 'Emotional Dimensions of Social Movements.' In The Blackwell Companion to Social Movements, edited by David A. Snow, Sarah A. Soule and Hanspeter Kriesi, 413-32. Malden, Mass.: Blackwell, 2004.

Iannello, Kathleen P. Decisions without Hierarchy: Feminist Interventions in Organization Theory and Practice. New York: Routledge, 1992.

Kirner, Joan and Moira Rayner. TheWomen's Power Handbook. Melbourne: Penguin, 1999.

Kokopeli, Bruce and George Lakey. Leadership for Change: Towards a Feminist Model. Philadephia: New Society Publishers, 1978.

McGregor Burns, James. Leadership. New York: Free Press, 1978.

McPhillips, Kathleen. 'Introduction.' In Local Heroes: Australian Crusades from the Environmental Frontline, edited by Kathleen McPhillips, xi-xxiv. Sydney: Pluto Press, 2002.

McPhillips, Kathleen, ed. Local Heroes: Australian Crusades from the Environmental Frontline. Sydney: Pluto Press, 2002.

Mercer, Jan, ed. The Other Half: Women in Australian Society. Melbourne: Penguin, 1975.

Meyer, David S. and Nancy Whittier. 'Social Movement Spillover.' Social Problems 41 (1994): 277-98.

Morris, Aldon D. and Suzanne Staggenborg. 'Leadership in Social Movements.' In The Blackwell Companion to Social Movements, edited by David A. Snow, Sarah A. Soule and Hanspeter Kriesi, 171-96. Malden, Mass.: Blackwell, 2004.

Moss Kanter, Rosabeth. Men and Women of the Corporation. New York: Basic Books, 1977. 
15. Collectivism, consensus and concepts of shared leadership in movements for social change

O'Connor, Karen and Alixandra B. Yanus. 'Overview: History of Women Leaders in Social Movements.' In Gender and Women's Leadership: A Reference Handbook. Volume 1, edited by Karen O'Connor, 181-7. New York: Sage, 2010 .

Robnett, Belinda. How Long? How Long? African American Women in the Struggle for Civil Rights. New York: Oxford University Press, 1997.

Rosener, Judy. 'Ways Women Lead.' Harvard Business Review (NovemberDecember 1990): 119-25.

Sawer, Marian. Sisters in Suits: Women and Public Policy in Australia. Sydney: Allen \& Unwin, 1990.

Sawer, Marian. 'Femocrats and Ecorats: Women's Policy Machinery in Australia, Canada and New Zealand.' In Missionaries and Mandarins: Feminist Engagement with Development Institutions, edited by Carol Miller and Shahra Razavi, 112-37. London: Intermediate Technology Publications, 1998.

Sawer, Marian. Making Women Count. A History of the Women's Electoral Lobby in Australia. Sydney: UNSW Press, 2008.

Sawer, Marian and Abigail Groves. “The Women's Lobby": Networks, Coalition Building and the Women of Middle Australia.' Australian Journal of Political Science 29 (1994): 435-59.

Simon, Herbert A. 'A Behavioral Model of Rational Choice.' Quarterly Journal of Economics 69 (1955): 99-118.

Sinclair, Amanda. 'Not Just "Adding Women In": Women Re-Making Leadership.' Paper presented at the Women, Leadership and Democracy in Australia Conference, Museum of Australian Democracy, Canberra, 1-2 December 2011.

Sinclair, Amanda and Fern Marriott. 'Women in Management-Advantage through Adversity.' Asia Pacific Human Resource Management 28 (1990): $14-25$.

Staggenborg, Suzanne. 'Can Feminist Organizations be Effective?' In Feminist Organizations: Harvest of the New Women's Movement, edited by Myra Marx Ferree and Patricia Yancey Martin, 339-55. Philadelphia: Temple University Press, 1995.

Stivers, Camilla. 'Women as Leaders in the Progressive Movement.' In Gender and Women's Leadership: A Reference Handbook. Volume 1, edited by Karen O'Connor, 188-95. New York: Sage, 2010. 
Tanner, Kerry Jeanne. 'Emotion, Gender and the Sustainability of Communities.' Community Informatics: A Global E-Journal 1 (2005). http://ci-journal.net/ index.php/ciej/article/view/208/165.

Taylor, Verta. 'Gender and Social Movements: Gender Processes in Women's Self-Help Movements.' Gender and Society 13 (1999): 8-33.

Taylor, Verta and Nella van Dyke. "“Get Up, Stand Up": Tactical Repertoires of Social Movements.' In The Blackwell Companion to Social Movements, edited by David A. Snow, Sarah A. Soule and Hanspeter Kriesi, 262-93. Malden, Mass.: Blackwell, 2004.

Wajcman, Judy. 'Desperately Seeking Differences. Is Management Style Gendered?' British Journal of IndustrialRelations 34 (1996): 333-49.

Weeks, Wendy. 'Feminist Principles for Community Work.' Women in Welfare Education, 7 October 2004: 1-16 [reprinted from Women in Welfare Education 1 (1994)].

Weeks, Wendy. 'Democratic Leadership Practices in Australian Feminist Women's Services: The Pursuit of Collectivity and Social Citizenship?' International Review of Women and Leadership 2 (1996): 19-33.

Wensing, Veronica. 'What's Behind a Name? The Organisational Identity of Rape Crisis Centres: Positioning the Canberra Rape Crisis Centre as a Feminist Organisation in the 21st Century.' Unpublished paper, 2009.

Wolf, Naomi. Fire with Fire: The New Female Power and How to Use It. London: Chatto \& Windus, 1993. 
This text taken from Diversity in Leadership: Australian women, past and present, edited by Joy Damousi, Kim Rubenstein and Mary Tomsic, published 2014 by ANU Press, The Australian National University, Canberra, Australia. 